\title{
Passengers Perception of Service Providers at Railway Platforms in India: A Comparative Analysis
}

\author{
Mohit Kumar Ojha, Himani Upreti, Rupa Khanna Malhotra, Oshin Parasar
}

\begin{abstract}
The study is an attempt to measure satisfaction level of passengers for different platform-based amenities and service providers at railway platforms in India. The study is conducted at Allahabad Junction Railway Station, one of the busiest station in North Central Railway (NCR) Zone of Indian Railways. Study tried to compare the performance of service providers based on whether private vendor and railway operated ones. For the purpose a total of 23 amenities in five categories have been selected for the study.Diagnostic research adopting observation and survey method using questionnaire technique was used. Mean and standard deviation has been calculated to measure the level of performance of various service providers while gap analysis is used to compare their relative performance. Overall it is concluded that Book stalls, drinking water and other facilities like reservation display boards and so on provide maximum satisfaction, while, personal hygiene has least satisfaction level. Satisfaction level is high for services provided private operators as compared to those provided by Indian Railways.
\end{abstract}

Key Words: Platform-Based Amenities, Satisfaction Level, Indian Railway, Allahabad Junction, Gap Analysis

\section{INTRODUCTION}

Service has attained huge importance in today's economy and is justified by the emergence of the term 'economy of services' (Urban, 2010). Service organizations have to understand the expectations of its customers and fulfill those expectations by providing quality services (Parasuraman, Zethaml and Berry, 1988). Satisfaction can be expressed as matching of customer's service expectation and actual service delivery. It can be referred to as the result of individual service transaction and complete service encounter (Johnston, 1995). As per Transit Cooperative Research Program (TCRP) Report 100, quality of service reflects the passenger's perception of transit performance; Givoni and Rietveld (2007) opine that quality of stations has a positive impact on the overall perception of passengers for rail journey.

Indian Railways has a country wide network and is a major service provider of the country and to combat the onslaught from air and road transport, railway is mulling multiple innovations.

Revised Manuscript Received on April 25, 2019.

Dr. Mohit Kumar Ojha*, Assistant Professor, Graphic Era Deemed to be University, Dehradun, India. E-mail: dr.mohitojha@gmail.com

Ms. Himani Upreti, Assistant Professor, Graphic Era Deemed to be University, Dehradun, India.

Dr. Rupa Khanna Malhotra, Professor, Graphic Era Deemed to be University, Dehradun, India.

Oshin Parasar, Assistant Professor, Graphic Era Hill University, Dehradun, India.
In this regard, it is pertinent to measure the quality of service deliver at railway platforms of Indian Railways. In this direction, present study is an attempt to assess the level of service delivery and performance of different service providers at one of the busiest railway station in India, namely, Allahabad Junction in the North Central Railway (NCR) Zone of Indian Railways.

\section{THEATRICAL BACKGROUND}

Several studies have been done in national and international context covering various aspects of railways considering the generic dimensions of service quality like refreshment, security, ambiance, information provision, behavioural aspects, and so on; a few studies have also studied services at railway platforms.

TCRP Report 100 (2000) identifies eight categories to measure service quality namely availability of transit service, service monitoring, community, travel time, safety and security, maintenance and construction, economy and capacity. Doi et al. (2003) have studied Metro Rail Transit 3 (MRT3) stations of Metro Manila, Philippines to identify the cause of low ridership from the point of view of accessibility and intermodality. Geetika and Nandan (2010) identified 16 factors to measure passenger satisfaction. They found out that quality of refreshments and behavior of staff, were most important for customer satisfaction at railway platforms. A report by The Gallup Organization (2011) identified dimensions of ease of buying tickets, provision of information about train schedules/platform and personal security as major factors for satisfaction, and lack facilities for car parking, quality of facilities and services and cleanliness/good maintenance of station facilities were major dissatisfaction. Gupta and Datta (2012) have considered attributes of accessibility, extent of waiting, information availability, passenger amenities, security and travel related facilities. As shown by the results extent of waiting, security and travel related facilities are the attributes with which passengers were most dissatisfied.

Vishnuvarthani \& Selvaraj (2012) in their study of Salem Division of Southern Railway, India concluded that majority of sample passengers were unaware or have low level of awareness about the services provided by railways and at the same time around 83.8 per cent of the sample passengers were dissatisfied with the services provided at the railway platforms. Result also shows that there is a positive correlation between the awareness factors and satisfaction factors.

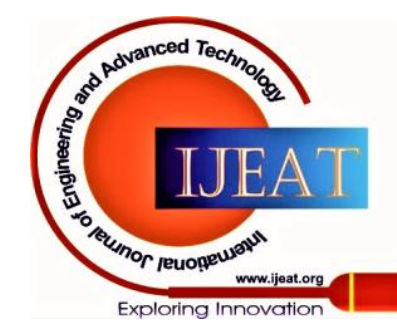


Further, they concluded that individual expenditure, class of travel \& mode of ticket reservation are positively associated with the level of awareness of passengers. Vishnuvarthani \& Selvaraj (2013) assert that assessing the awareness level is of immense importance because until and unless passengers know about the utilities they will not use them. So, it is vital to inform the passengers about various amenities available at railway platforms. Hanna\& Kaufmann (2014) have concluded in their study on High-Speed Rail (HSR) Stations in United States that location of station within the city, the size of the station, accessibility \& intermodality and appearance $\&$ serviceability of stations are the major factors that has to be considered before construction of a railway station. Geetika et al. (2016) in a study of Allahabad Junction Railways station had concluded that station premises were lacking in terms of quality of services offered to passengers while they found that food and beverages and cleanliness were the factors significantly affecting passengers' overall satisfaction. Further in a study on Kanpur Central Railway station, Ghosh et al. (2017) have reported that cleanliness and hygiene level was at its lowest and passengers were extremely dissatisfied with the quality of urinals, drinking water facility and quality of eatables offered at stations.

However, most of the studies relate to the services as such and not the service providers. This study aims to measure the satisfaction level of customers with respect to various services providers at Allahabad Jn. railway station. The present study considers individual service providers in the categories of food and beverages, book stalls, personal hygiene and water facilities, internet and telecommunication facilities, basic amenities for passengers. In all 23 different amenities have been included in the study and the satisfaction level is measured for each of these amenities.

Study aims to measure satisfaction level of passengers for different amenities and service providers available at platforms of Allahabad Junction. Study also tried to assess the difference between satisfaction level of passengers for facilities provided by private vendors and those provided directly by railway. The study focuses on the specific service providers and satisfaction level for each of these service providers under respective categories is measured.

\section{RESEARCH METHODOLOGY:}

Observation method is applied to draw an exhaustive list of amenities. For the sake of simplification and comparison, 23 amenities had been divided under five broad categories. The questionnaire has been drafted in four parts on selected amenities on the basis of their accessibility to the passenger. The questions relate to biographical profile of passenger, awareness-usage status sought via dichotomous questions in the form of 'Yes' and 'No', satisfaction level of respondents for selected amenities by different service providers (5 Point Likert type scale has been used, where 1 represent highly dissatisfied and 5 represent highly satisfied) and finally open ended questions were asked to seek suggestions from respondents to improve the platform and to make their transit stay at stations more comfortable and pleasurable.

\section{DATA ANALYSIS AND INTERPRETATION:}

The observation process shows that basic amenities like water points, foot over bridge, platform display, reservation display etc. are present on each platforms and are well functioning, but the more specific facilities like restaurants, ATMs, escalators medical facility, waiting hall, Sulabh Sauchalaya, enquiry counters etc. are concentrated on platform 1. It was also found that Platform Enquiry Machine was not functioning on any of the platforms except on platform 1 though it was available on every platform (Annexure 1).

The amenities selected have been classified on the basis of service provider i.e. private vendor and directly by railway andit can be seen that 13 services are being provided by private vendors. The facilities provided by private vendors comprise of food and beverages, book stalls, personal hygiene. Basis facilities like drinking water, platform display, enquiry counters, and so onare provided directly by railway.

\section{SATISFACTION LEVEL OF PASSENGERS:}

To analyze the satisfaction level of passengers, mean and standard deviation has been calculated for each individual amenity (on the basis of service provider) and composite mean value is also calculated for each of the five categories selected for the study. For calculating the mean value and $\mathrm{SD}$, only affirmative responses are considered. Non-user responses have not been considered (Refer to Table 1).

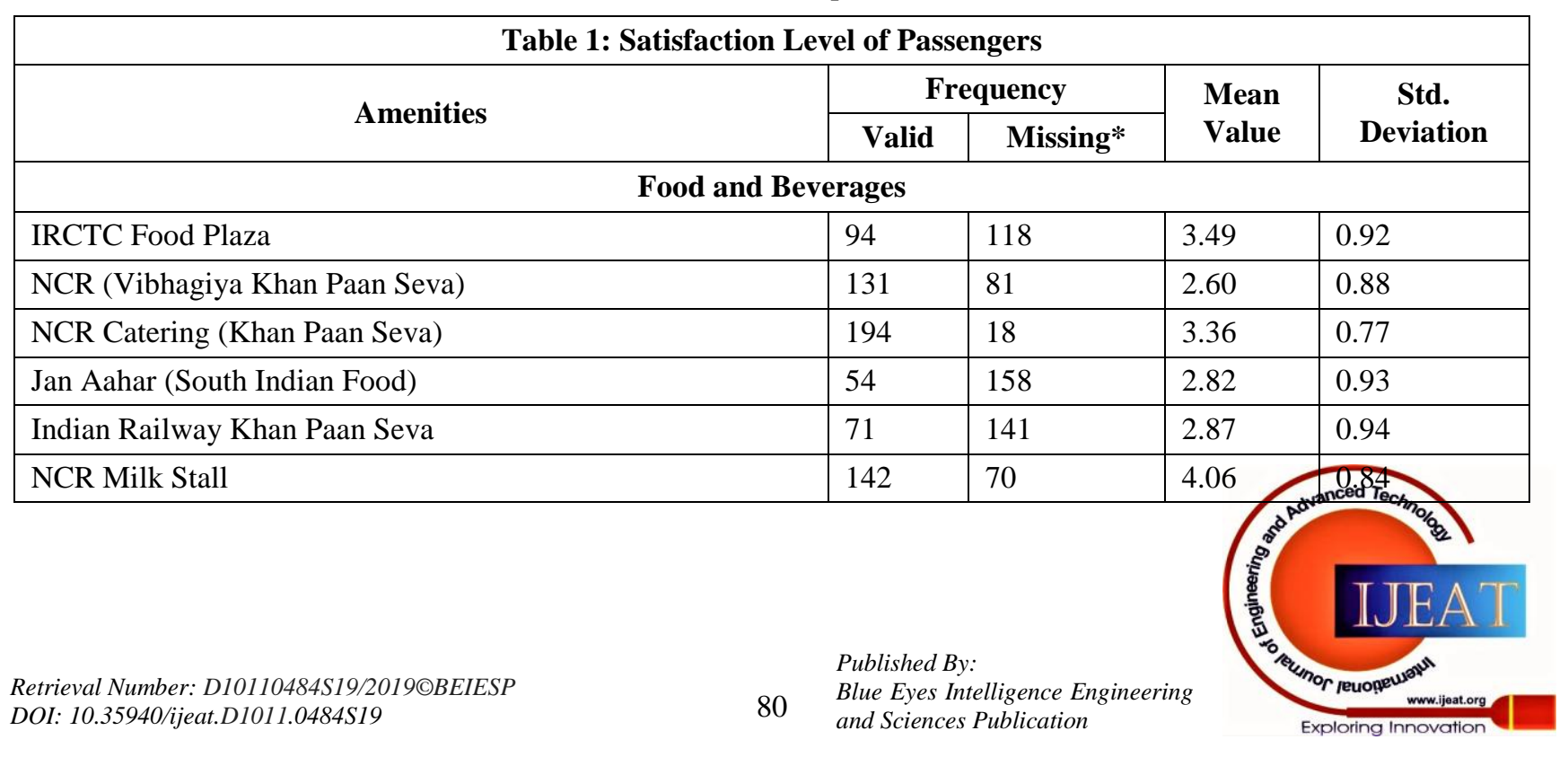




\begin{tabular}{|c|c|c|c|c|}
\hline \multicolumn{5}{|c|}{ Book Stall } \\
\hline A. H. Wheeler & 105 & 107 & 4.13 & 0.78 \\
\hline Sarvodaya Sahitya & 43 & 169 & 4.23 & 0.75 \\
\hline Shikshit Berozgar Mudran and Prakashan Sehkari Ltd. & 8 & 204 & 2.75 & 0.7 \\
\hline Ram Krishan -Vivekanand Vedanta Sahitya & 32 & 180 & 4.16 & 0.98 \\
\hline \multicolumn{5}{|c|}{ Personal Hygiene } \\
\hline Urinal (Free) & 194 & 18 & 1.5 & 0.82 \\
\hline Urinal (Pay and Use) & 187 & 25 & 1.96 & 0.97 \\
\hline Sulabh Sauchalaya & 154 & 58 & 2.49 & 0.99 \\
\hline \multicolumn{5}{|c|}{ Communication and Banking Facilities } \\
\hline PCO/STD/ISD/Internet & 49 & 163 & 3.04 & 0.76 \\
\hline ATMs & 149 & 63 & 3.55 & 0.86 \\
\hline \multicolumn{5}{|c|}{ Drinking Water and Other Facilities } \\
\hline Water Point & 206 & 6 & 3.51 & 1.08 \\
\hline Waiting Hall (Seating Chairs) & 199 & 13 & 3.75 & 0.76 \\
\hline May I Help You & 102 & 110 & 3.07 & 0.89 \\
\hline Platform Display & 195 & 17 & 4.28 & 0.744 \\
\hline Platform Enquiry Machine & 117 & 95 & 2.03 & 1.23 \\
\hline Reservation Display Board & 177 & 35 & 4.29 & 0.87 \\
\hline Escalator & 163 & 49 & 2.87 & 0.89 \\
\hline Cloak Room & 52 & 160 & 3.42 & 0.91 \\
\hline
\end{tabular}

As evident from Table 1, it is inferred that in food and beverages satisfaction level of passengers is highest for NCR Milk Stall with mean value of 4.06, which suggests that passengers are more than moderately satisfied with the service quality of Milk Stall. The lowest mean value is of NCR Vibhagiya Khan Paan Seva having mean value around 2.6. Maximum deviation is recorded for Indian Railway Khan Paan Seva while minimum deviation is for NCR Catering. Overall Satisfaction level of NCR catering is maximum as the standard deviation is minimum while maintaining a healthy satisfaction level of 3.35.

In the category of book stall Sarvodaya Sahitya has maximum satisfaction level with mean value of 4.23 , which shows that passengers are very much satisfied with its services, while minimum satisfaction level is of SBMPSL with mean value is just 2.75. Maximum deviation is recorded in Ram Krishan-Vivekanand Vedanta Sahitya with std. deviation of 0.99 while lowest deviation is for SBMPSL which is mainly because very few respondents have rated their satisfaction level for SBMPSL. Overall, Sarvodaya Sahitya delivers maximum satisfaction to the passengers.

In case of personal hygiene, none of the item managed to attain a satisfaction level of 2.5. Highest mean value is of Sulabh Sauchalaya (2.49) and lowest is of Free Urinal (1.5). Deviation is also very high for each of the items; overall Sulabh Sauchalaya seems to provide maximum satisfaction to passengers, although usage level is very low.

Talking about communication and banking facilities, we can clearly identify that ATMs have maximum satisfaction level with mean value of 3.55 but its deviation is on a higher side. STD/PCO booth recorded low deviation as compared to ATMs because only 49 respondents have rated their satisfaction level against it.

Finally, in case of drinking water and other facilities, Reservation Display Board has highest satisfaction level (4.29) followed by Platform Display (4.28). Deviation is maximum for Platform Enquiry Machine (1.23) followed by Water Point (1.08). Overall it can be said that in this category platform display provides maximum satisfaction for passengers as it has high mean value for satisfaction level and low standard deviation.

\section{GAP ANALYSIS}

To conduct gap analysis, mean score of importance scale (for overall groups of amenities only) and satisfaction scale has been computed for each individual amenity (on the basis of service provider). While calculating mean score, non-user responses have not been considered.

Overall the satisfaction level from all the utilities combined together as shown in Table 2 is 3.20 as against average level of importance placed at 4.39 , thereby, registering a gap of 1.19 points. Considering individual amenities, urinal facility and platform enquiry machine have registered highest gap in terms of passengers' perception of importance of those amenities as against their respective satisfaction out of it. It shows that level of cleanliness and hygiene are sub-standard at Allahabad Junction Railways Station as gap in importance and satisfaction score for water point is also on a higher side registering 1.19 points.

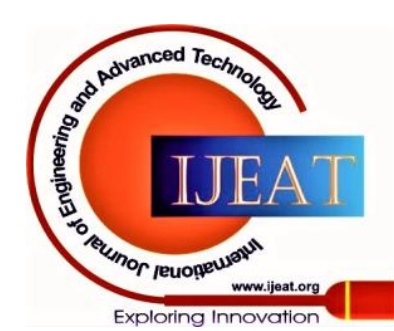


All service providers in food and beverage category except milk stall ( 0.47 points) have registered gap score above 1 , while three of them, namely; NCR (Vibhagiya Khan Paan Seva),

Jan Aahar, and Indian Railways Khan Paan Seva have registered gap score above 1.5. Only one amenity, namely, Reservation Display Board has reported negative gap score of -0.02 and hence which shows highest satisfaction level of 4.29 out of 5 and hence out-perform the importance score.

Another utility that closely matched the performance standard is platform display registering mean satisfaction score of $4.28 \mathrm{~S}$ against importance score of 4.32 and hence having a gap of just 0.04 points.

Other amenities registering gap score of above one are, Shikshit Berozgar Mudran and Prakashan Sehkari Ltd., May I Help You (enquiry counters), Escalators and ATMs. Overall it can be said that performance of amenities under food and beverage categories and personal hygiene categories are below par which can be attributed to the fact that there prevail unhealthy environment and improper maintenance of these amenities.

\begin{tabular}{|c|c|c|c|c|}
\hline \multicolumn{5}{|c|}{ Table 2: Gap Score for Individual Amenities } \\
\hline Sr. No. & Utilities & $\begin{array}{c}\text { Mean Score } \\
\text { (Importance } \\
\text { Scale }\end{array}$ & $\begin{array}{c}\text { Mean Sore } \\
\text { (Satisfaction } \\
\text { Scale) }\end{array}$ & Gap Score \\
\hline 1 & IRCTC Food Plaza & 4.53 & 3.49 & 1.04 \\
\hline 2 & NCR (Vibhagiya Khan Paan Seva) & 4.53 & 2.6 & 1.93 \\
\hline 3 & NCR Catering (Khan Paan Seva) & 4.53 & 3.36 & 1.17 \\
\hline 4 & Jan Aahar & 4.53 & 2.82 & 1.71 \\
\hline 5 & Indian Railway Khan Paan Seva & 4.53 & 2.87 & 1.66 \\
\hline 6 & NCR Milk Stall & 4.53 & 4.06 & 0.47 \\
\hline 7 & A. H. Wheeler & 4.51 & 4.13 & 0.38 \\
\hline 8 & Sarvodaya Sahitya & 4.51 & 4.23 & 0.28 \\
\hline 9 & $\begin{array}{l}\text { Shikshit Berozgar Mudran \& Prakashan } \\
\text { Sehkari Ltd. }\end{array}$ & 4.51 & 2.75 & 1.76 \\
\hline 10 & Ram Krishan-Vivekanand Vedanta Sahitya & 4.51 & 4.16 & 0.35 \\
\hline 11 & Water Point & 4.67 & 3.51 & 1.16 \\
\hline 12 & Urinal (Free) & 4.07 & 1.5 & 2.57 \\
\hline 13 & Urinal (Pay \& Use) & 4.07 & 1.96 & 2.11 \\
\hline 14 & Sulabh Sauchalaya & 4.07 & 2.49 & 1.58 \\
\hline 15 & Waiting Hall (Seating Chairs) & 4.41 & 3.75 & 0.66 \\
\hline 16 & May I Help You & 4.27 & 3.07 & 1.2 \\
\hline 17 & Platform Display & 4.32 & 4.28 & 0.04 \\
\hline 18 & Platform Enquiry Machine & 4.41 & 2.03 & 2.38 \\
\hline 19 & Reservation Display Board & 4.27 & 4.29 & -0.02 \\
\hline 20 & Escalator & 4.69 & 2.87 & 1.82 \\
\hline 21 & Cloak Room & 4.37 & 3.42 & 0.95 \\
\hline 22 & PCO/STD/ISD/Internet & 3.39 & 3.04 & 0.35 \\
\hline 23 & ATMs & 4.79 & 3.55 & 1.24 \\
\hline & Overall Satisfaction Level & 4.39 & 3.2 & 1.19 \\
\hline
\end{tabular}

\section{COMPARATIVE ANALYSIS ON THE BASIS OF SERVICE PROVIDERS}

In this study, only food \& beverages category has been qualified for drawing a comparison between private vendors and railway operators as on Allahabad Junction it is the only category where both Indian Railways as well as private players operate and hence compete with each other. There are six different service providers in food and beverage category at Allahabad junction, three each from private players and Indian Railways. Private operated ones are: IRCTC Food Plaza operated by Neelam Restaurant, NCR Catering (Khan Paan Seva) operated by private vendors selected by Indian Railways via tenders and NCR Milk Stalls operated by Parag and Amul. Service providers belonging to Indian Railways are: NCR Vibhagiya Khan Paan Seva operated by zonal railways, Jan Aahar and Indian

Railways Khan Paan Seva both operated directly by Indian Railways. Table 3 shows that passengers have placed high importance for this category of amenity as the mean importance level placed by passengers is 4.53 .

Comparison has been made for different service providers as against importance placed by passengers. It is evident from Table 3 that none of the service provider has been able to meet the level of importance placed by passengers; performance of private vendors is still somewhat satisfactory as all three have been able to register mean satisfaction level in excess of 3 which signifies passengers are satisfied with the performance and service delivery of those vendors. Outlets operated by Indian Railways have fallen behind as all three providers have mean satisfaction level less than 3

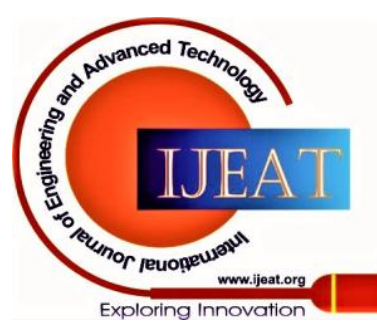


which clearly highlights abysmal performance of Indian Railways operated food stalls.

Considering individually, passengers have rated NCR Milk Stall as best performing food and beverage outlet registering mean satisfaction score of 4.06 which is very close to the importance level placed by passengers for food and beverages. Worst satisfaction level has been recorded for NCR Vibhagiya Khan Paan Seva hence we can infer that passengers are not satisfied with the performance and service delivery of food stalls operated by zonal railways.

\begin{tabular}{|c|c|c|c|}
\hline Operated by & Utilities & $\begin{array}{c}\text { Importance Level } \\
\text { (Mean) }\end{array}$ & $\begin{array}{c}\text { Satisfaction Level } \\
\text { (Mean) }\end{array}$ \\
\hline \multirow{3}{*}{ Indian Railways } & Jan Aahar (South Indian Food) & \multirow{6}{*}{4.53} & 2.82 \\
\hline & NCR (Vibhagiya Khan Paan Seva) & & 2.60 \\
\hline & Indian Railway Khan Paan Seva & & 2.87 \\
\hline \multirow{3}{*}{ Private Vendors } & IRCTC Food Plaza & & 3.49 \\
\hline & NCR Catering (Khan Paan Seva) & & 3.36 \\
\hline & NCR Milk Stall & & 4.06 \\
\hline
\end{tabular}

\section{CONCLUSIONS AND RECOMMENDATIONS}

To conclude it can be said that the study throws important information regarding state of affairs at railway station as the study is conducted at a major junction of NCR Zone of Indian Railways. The findings show that people are willing to pay for services provided quality is assured. Quality of eatables has emerged as a major issue. Further, the biggest challenge before railway is to create hygienic environment as the findings reveal least satisfaction level for cleanliness. They also have to work to make people aware of the facilities available at railway stations by proper maintenance and positioning. Railway has to put its effort forward to change the scenario of railway platforms and make it more like metro rail platforms. The ray of hope is that a large number of passengers were by and large satisfied with large number of amenities.

As the outcome of this study, it is recommended that cleanliness and hygiene of railway platforms need to be improved and it should be ensured that every aspect of railway platforms concourse area, water points, rail tracks, waiting lounges, seating area and washrooms should be clean and hygiene. Further it is recommended to provide ample security for passengers and their luggage and for that proper security mechanism has to be in place with the likes of metal detector, scanning machine, restricted entry and so on. There should be proper arrangement of seating for passengers so that they can relax and spend their stay with more comfort and ease. For that, there must be provision of retiring rooms, waiting rooms and proper seating facility on every platform. Further to look after the needs of 'divyang' and old aged people, Upward and downward Escalators should be provided on every platform to facilitate platform inter-change. There should be provision of proper medical facility including dispensary, medical store and ambulance and railway authorities should ensure proper its functioning. Additionally, it is recommended that enquiry counter, television display for train running status, and so on should be available on every platform, while entertainment facility like TV and indoor games and recreation facility should be provided so that passengers can enjoy while waiting for their trains at platforms.

\section{MANAGERIAL IMPLICATION, RESEARCH LIMITATIONS AND SCOPE FOR FUTURE RESEARCH:}

The study may prove to be of immense use for administration and policy makers as it considers specific services for measuring service quality and performance of service providers. The results of the study provide a clear framework for improving service delivery at railway stations. The study identified various dimensions which provide high satisfaction level to passengers and railway can use those dimensions for improving their future plan of actions.

The major limitation of the study is sample size as it is conducted at one station. A bigger picture could emerge if it was conducted on number of stations. However, this limitation also presents an opportunity for further research.

\section{REFERENCES}

1. Geetika and Nandan, S., 2010, Determinants of customer satisfaction on service quality: a study of railway platforms in India, Journal of Public Transport, 13(1), pp. 97-113.

2. Geetika, Ghosh, P., Ojha, M. K., and Kumar, S. (2016). Journey towards World Class Stations: An Assessment of Platform Amenities at Allahabad Junction. Journal of Public Transportation, 19(1), 6883.

3. Ghosh, P., Ojha, M. K. and Geetika. (2017), Determining passenger satisfaction out of platform-based amenities: A study of Kanpur Central Railway Station. Transport Policy, 60, 108-118.

4. Givoni, M. and Rietveld, P., 2007, The access journey to the railway station and its role in passengers' satisfaction with rail travel, Transport Policy, 14, pp. 357-365.

5. Gronroos, C.,1984, A service quality model and its marketing implication,European Journal of Marketing, 18, pp. 36-44.

6. Gupta, S. and Datta, R., 2012, Prioritizing service attributes for quality up gradation of Indian railway stations, The TQM Journal, 24(2), pp. 167-180.

7. Hanna, F. and Kaufmann, J. (2014). Factors that influence the success of HSR Stations.International Journal of Research in Engineering and Technology, 3(6), 1-7.

8. Johnston, R., 1995, The determinants of service quality: satisfiers and dissatisfiers, International Journal of Service Industry Management, 6(5), pp. 53-71.

9. Parasuraman, Zelthaml, V. A. and Malhotra A., 2005, E-S-QUAL A multiple-item scale for assessing electronic service quality, Journal of Service Research, March, 7(X), pp. 1-21. 
10. Parasuraman, A., Zethaml, V. A. and Berry, L. L., 1988 , SERVQUAL: a multiple-item scale for measuring consumer perceptions of service quality, Journal of Retailing, 64(1), pp. 12-40.

11. Report 100, Transit Capacity and Quality of Service Mannual, $2^{\text {nd }}$ ed., Transit Cooperative Research Program (TCRP), 2009, part 3, pp. 327.

12. Singh, B. and Kumar, D., 2014, Customer satisfaction analysis of services of Delhi Metro,Asian Journal of Multidisciplinary Studies, 2(1), pp. 124-130.

13. The Gallup Organization,2011, Survey on passengers' satisfaction with rail survey, European Commission, retrieved from: http://ec.europa.eu/public_opinion/flash/fl_326_en.pdf, doa: $15 / 03 / 2014$.
14. Urban, W., 2010, Customers' experience as a factor affecting perceived service quality, Economics and Management, 15, pp. 820 826.

15. Vishnuvarthani, S. and Selvaraj, A. (2012). Railway Passengers' satisfaction: a study in Salem Division of Southern Railway.International Journal of Advanced Research in Management and Social Sciences, 1(6), 92-101.

16. Vishnuvarthani, S. and Selvaraj, A. (2013). Railway passengers' awareness on services: a study in Salem Division of Southern Railway.The International Journal of Management, 2(1), 1-15.

Annexure 1

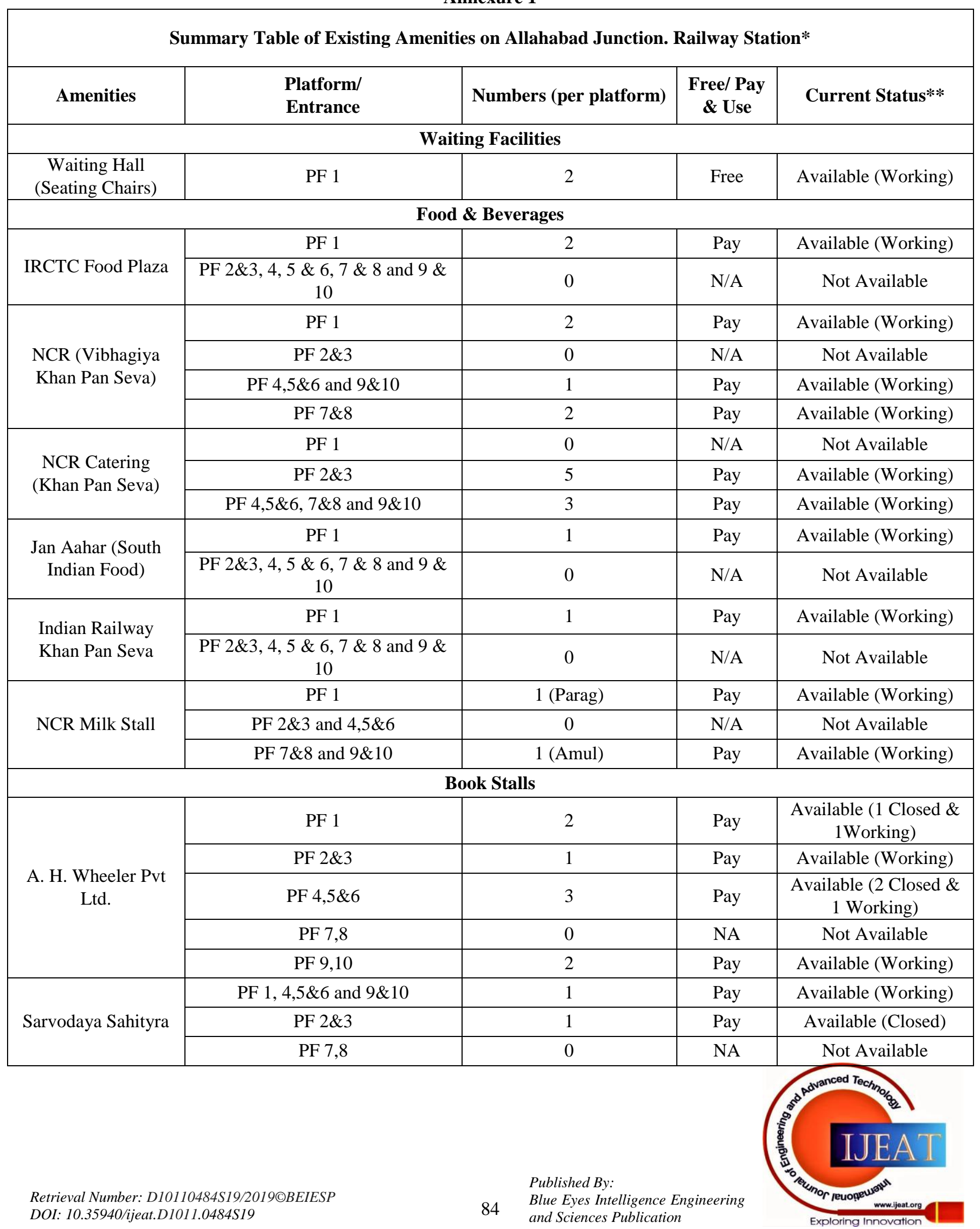




\begin{tabular}{|c|c|c|c|c|}
\hline \multirow{2}{*}{$\begin{array}{l}\text { Shikshit Berozgar } \\
\text { Mudran \& } \\
\text { Prakashan Sehkari } \\
\text { Ltd. }\end{array}$} & PF $1,2 \& 3,4,5 \& 6$ and $9 \& 10$ & 0 & $\mathrm{NA}$ & Not Available \\
\hline & PF 7,8 & 2 & Pay & Available (Closed) \\
\hline \multirow{2}{*}{$\begin{array}{l}\text { Ram Krishn- } \\
\text { VivekaN/And } \\
\text { Vedanta Sahitya }\end{array}$} & PF 1 & 1 & Pay & Available (Working) \\
\hline & $\begin{array}{c}\text { PF } 2 \& 3,4,5 \& 6,7 \& 8 \text { and } 9 \& \\
10\end{array}$ & 0 & N/A & Not Available \\
\hline \multicolumn{5}{|c|}{ Personal Hygiene } \\
\hline \multirow[t]{2}{*}{ Urinal (Free) } & $\begin{array}{c}\text { Entrance (City Side), PF } 2 \& 3, \\
4,5 \& 6,7 \& 8,9 \& 10 \text { and Entrance } \\
\text { (Civil lines side) }\end{array}$ & 1 & Free & Available (Working) \\
\hline & PF 1 & 0 & N/A & Not Available \\
\hline \multirow[t]{3}{*}{ Urinal (Pay \& Use) } & $\begin{array}{c}\text { Entrance (City Side), PF } 2 \& 3 \text { and } \\
9 \& 10\end{array}$ & 0 & N/A & Not Available \\
\hline & PF $1,4,5 \& 6$ and $7 \& 8$ & 1 & Pay & Available (Working) \\
\hline & Entrance (Civil Lines Side) & 1 & Pay & Available (Working) \\
\hline \multirow[b]{2}{*}{ Sulabh Sauchalaya } & Entrance (City Side) & 1 & Pay & Available (Working) \\
\hline & $\begin{array}{l}\text { PF 1, 2\&3, 4,5\&6, 7\&8, 9\&10 } \\
\text { and Entrance (Civil lines side) }\end{array}$ & 0 & N/A & Not Available \\
\hline \multicolumn{5}{|c|}{ Medical Facility } \\
\hline \multirow{3}{*}{ First aid Room } & PF 1 and $4,5 \& 6$ & 1 & Pay & Available (Closed) \\
\hline & PF 2,3 and $9 \& 10$ & 0 & NA & Not Available \\
\hline & PF 7,8 & 1 & Pay & Available (Working) \\
\hline \multicolumn{5}{|c|}{ Drinking Water } \\
\hline \multirow{5}{*}{ Water Point } & PF 1 & 9 & \multirow{5}{*}{ Free } & $\begin{array}{l}\text { All Available } \\
\text { (Working) }\end{array}$ \\
\hline & PF 2\&3 & 10 & & $\begin{array}{l}\text { All Available } \\
\text { (Working) }\end{array}$ \\
\hline & PF 4,5 \& 6 & 14 & & $\begin{array}{l}\text { Available (1 Not } \\
\text { Working) }\end{array}$ \\
\hline & PF $7 \& 8$ & 18 & & $\begin{array}{l}\text { All Available } \\
\text { (Working) }\end{array}$ \\
\hline & PF $9 \& 10$ & 11 & & $\begin{array}{l}\text { Available (2 Not } \\
\text { Working) }\end{array}$ \\
\hline \multicolumn{5}{|c|}{ Communication } \\
\hline \multirow{4}{*}{$\begin{array}{l}\text { PCO/STD/ISD } \\
\text { (Internet/Fax) }\end{array}$} & PF 1 & 1 & Pay & Available (Working) \\
\hline & PF 2,3 and $9 \& 10$ & 0 & N/A & Not Available \\
\hline & PF 4,5\&6 & 1 & Pay & $\begin{array}{l}\text { Available (Not } \\
\text { working) }\end{array}$ \\
\hline & $\mathrm{PF} 7 \& 8$ & 1 & Pay & Available (Closed) \\
\hline \multicolumn{5}{|c|}{ ATM's } \\
\hline \multirow{3}{*}{ ATMs } & Entrance (City Side) & 4 & Free & Available (Working) \\
\hline & $\begin{array}{l}\text { PF } 1 \text { and Entrance (Civil lines } \\
\text { side) }\end{array}$ & 1 & Free & Available (Working) \\
\hline & PF $2,3,4,5 \& 6,7 \& 8$ and $9 \& 10$ & 0 & N/A & Not Available \\
\hline \multicolumn{5}{|c|}{ Services } \\
\hline \multirow{2}{*}{$\begin{array}{l}\text { May I Help You } \\
\text { (Enquiry) }\end{array}$} & PF 1 & 2 & Free & Available (Working) \\
\hline & $\begin{array}{c}\text { PF } 2 \& 3,4,5 \& 6,7 \& 8 \text { and } 9 \& \\
10\end{array}$ & 0 & N/A & Not Available \\
\hline PF Display & All Platforms & - & Free & Available (Working) \\
\hline PF Enquiry Machine & All Platforms & - & Free & \\
\hline $\begin{array}{l}\text { Retrieval Number: D1011 } \\
\text { DOI: } 10.35940 / \text { ijeat.D10 }\end{array}$ & $\begin{array}{l}\text { 184S19/2019@BEIESP } \\
.0484 S 19\end{array}$ & $\begin{array}{l}\text { Publishec } \\
\text { Blue Eye } \\
\text { and Scier }\end{array}$ & ering & \\
\hline
\end{tabular}


Passengers Perception of Service Providers at Railway Platforms in India: A Comparative Analysis

\begin{tabular}{|c|c|c|c|c|}
\hline $\begin{array}{l}\text { Reservation Display } \\
\text { Board }\end{array}$ & All Platforms & - & Free & Available (Working) \\
\hline \multirow{2}{*}{ Escalator } & $\begin{array}{l}\text { PF } 1 \text { and Entrance (Civil lines } \\
\text { side) }\end{array}$ & 1 & Free & Available (Working) \\
\hline & $\begin{array}{c}\text { PF } 2 \& 3,4,5 \& 6,7 \& 8 \text { and } 9 \& \\
10\end{array}$ & 0 & N/A & Not Available \\
\hline \multirow[t]{2}{*}{ Ramp Bridge } & $\mathrm{PF} 1,2 \& 3,4,5 \& 6$ & 1 & Free & Available (Working) \\
\hline & PF 7,8 and $9 \& 10$ & 0 & NA & Not Available \\
\hline Lighting & $\begin{array}{l}\text { All Platforms including both } \\
\text { entrance }\end{array}$ & - & Free & $\begin{array}{l}\text { Available } \\
\text { (Working-Except on } \\
\text { PF 4,5\&6 Near Pay \& } \\
\text { Use Urinal and } \\
\text { Extreme Corners of } \\
\text { All Platforms) }\end{array}$ \\
\hline \multicolumn{5}{|c|}{$\begin{array}{l}\text { Note: } \\
\text { * The observation of railway station has been done on different days and at different time of a day for a week. } \\
* * \text { Categorization under "Available" is as follows: } \\
\text { Working: The facility is properly functional and was open at the time of observation. } \\
\text { Closed: The facility is properly functional but was closed at the time of observation. } \\
\text { Not Working: The facility is not functional at all. }\end{array}$} \\
\hline
\end{tabular}

